\title{
Empty Category in Persian Relative Clauses
}

\section{Mahmoud MOBARAKI}

Jahrom University, Iran

mmobaraki@jahromu.ac.ir

\author{
Abolfazl MOSAFFA JAHROMI \\ Jahrom University, Iran \\ a.mosaffa.jahromi@gmail.com
}

\begin{abstract}
Empty categories are one of the fundamental parts of generativist's view towards language. Empty operators, the so-called null elements, which are syntactically active in relative clauses and possibly move into [spec, CP], have reportedly been found in different languages. However, there is no solid evidence for the existence of empty operators in Persian relative clauses. Despite this, syntactic evidences such as theta theory, argument structure and subjacency condition provide satisfactory provable tests in favor of their role in Persian grammar. Namely, Persian relative clauses contain resumptive pronouns which may be covert. Their movement into [spec, CP] can precisely account for subjacency effect in relative clauses. Resumptive pronouns can occupy the subject as well as the object position. This articles attempts to introduce empty operators to Persian syntax, and shows that in such a way it is possible to account for the peculiar behavior of the Persian complementizer "ke" and its obligatory nature.
\end{abstract}

Keywords: relative clause; resumptive pronoun; empty category; subjacency condition; predicate logic

\section{Povzetek}

Ničelne kategorije so eden izmed osnovnih idej generativističnega pogleda na jezik. Ničelni operatorji (tudi ničelni elementi), ki so skladenjsko aktivni v oziralnih odvisnikih in lahko preidejo $v$ [spec, CP], so že bili dokazani v številnih jezikih. Njihova uporabnost pa do sedaj še ni bila pokazana za oziralne odvisnike v perzijščini. Ne glede na to pa sklepamo, da se skladenjski pristopi kot so teorija theta, struktura argumenta in pogoj podstave izkazujejo kot zanesljivi testi, ki spodbujajo uporabo ničelnih operatorjev v perzijski slovnici. Oziralni odvisniki v perzijščini namreč vsebujejo rezumptivne zaimke, ki so lahko prikriti. Njihova sprememba v [spec, CP] lahko natančno pojasni vpliv sintaktične omejitve pojavljanja (angl. Subjacency effect) oziralnih odvisnikih. Razumptivni zaimki namreč lahko zasedejo položaj tako osebka kot tudi predmeta. Članek poskuša uvesti ničelne opratorje v perzijsko skladnjo in pokaže, da lahko na ta način razložimo značilno obnašanje perzijskega dopolnike "ke" ter njegove obvezne pojavnosti.

Ključne besede: oziralni odvisnik; rezumptivni zaimek; ničelna kategorija; pogoj podstave; logika povedka 


\section{Introduction}

One of the issues in government and binding theory is empty categories. These categories can appear as subject or object in clauses in different languages. Soundless categories are NP-trace, Wh-trace, PRO or pro (Haegeman, 1992). Empty categories form the fundamental part of the government and binding model. Although there have been some changes added to the theory in recent years, empty categories have played an important and considerable role in grammar, explaining many grammatical realities (Chomsky, 1995; Radford, 2006; Hornestein et al., 2006). Empty categories are the consequence of projection principle, which says that the structure and lexical information must have syntactic representation at all levels. In other words, it means that categories exist at all levels. The projection of lexical information at the syntactic level can have phonetic representation or not. In second alternation, this information represents an empty category. Although empty categories are phonetically empty, they - according to the trace theory, projection principle and binding theory - exist in mental representation. If the movement does not trace, much of the realities remain unjustifiable in language. Empty categories are the consequence of universal grammar principles, such as the ones which are provable in relative clauses.

There are also empty categories in Persian relative clauses which leave behind a trace. Traces are also under the subjacency principle and empty category principle from which deviation leads to ungrammaticality of the sentence (Riemsdijk \& Williams, 1986). The movement of constituents should also be considered in relative clauses. The question which arises here is whether movement happens in Persian relative clauses or not. In case the answer is "yes", the following questions is whether there is an evidence for this movement in Persian relative clauses. Regarding relative clauses, there exist three aproaches in previous findings: "ke: that" movement and empty operator movement. The first approach has been cited in Miremadi (2008, p. 175) in the framework of government and binding theory (GB). Miremadi considers "ke" as a wh-word which moves from its original position to the specifier position of the complementizer phrase (CP). Ahangar (2000) also like Miremadi (2008) accounts "ke" as a relative pronoun which moves obligatorily from its original position inside relative clause (RC) to the [spec, CP] and leaves behind a trace. This approach has been criticized with the explanation that "ke" is not a pronoun and hence it cannot move (Taghvaipour, 2005). The fact that Persian does not include relative pronoun is discussed by Safavi (1994, p. 191), Khayampour (1973, p. 116) also by Lazard (1957, p. 229) and Windfuhr (1978, p. 62).

The other approach for relative clause analysis in Persian considers movement of empty operator. This account is based on the assumption that an empty operator is like a covert relative pronoun and then moves to the [spec, CP]. In this approach, "ke" is defined as a complementizer. 
The third approach, cited in Youhanaee (1997, p. 88), provides a view in the framework of the minimalist program. She treats subject and direct object relative clauses by the movement of a null operator, while other types of relative clauses are base generated.

This article tries to show that a movement is also possible in Persian relative clauses, the issue for which up until now not enough linguistic evidence has been found to be either proven or rejected. This article will further explain the nature of this category, and present explanation why "ke" in Persian is obligatory.

\section{Materials and methods}

To study empty category in Persian relative clauses, the authors tried to consider on casual sentences which are used in standard Persian, and applied syntactic evidence such as theta theory, argument structure and subjacency condition to find further evidence which support the existence of empty category and its behavior in Persian.

\section{Discussion}

\subsection{Relative clause}

From the view of language typology, three types of relative clauses can be defined according to the lexical arrangement. In post-nominal type, a relative clause comes after a noun (head). In prenominal type, a relative clause comes before a noun (head) and in adnominal type a head (noun) comes within a relative clause. Persian belongs to the third type, where a relative clause is used after a noun according to Comrie (1989, p. 139), as in the following example.

(1) pesar-i [ke shenā mi-konad] Farānsavi.

boy-RES ${ }^{1}$ [COMP swim PRES-do-3sg] French

'The boy who is swimming is French.'

Persian relative clauses always start with "ke", which is necessary for a sentence to be grammatically correct. Example (2) shows grammatically incorrect sentence.

\footnotetext{
${ }^{1}$ This particle precedes restrictive relative clauses in Persian and is shown, henceforth, by RES in gloss.
} 
(2) *pesar-i [shenā mi-konad] Farānsavi ast.

boy-RES [swim PRES-do-3sg] French be-PRES-3sg.

'The boy is swimming is French.'

This characteristic differentiates the usage of a "ke- clause" after a noun from the usage of a "ke- clause" in the object position of some verbs such as "dānestan" (to know), "goftan" (to say) etc. In applying a "ke-clause" as one of the arguments of the verb, "ke" is optional and can be deleted:

(3) mi-dān-am [ke mi-āy-ad.]

PRES-know-1sg [COMP PRES-come-3sg.]

'I know that s/he comes.'

(4) mi-dān-am [mi-āy-ad].

PRES-know-1sg [PRES-come-3sg].

'I know s/he comes.'

Dependent clauses in Persian always come with a "ke" as a complementizer, and are thus called complementizer clauses.

\subsection{Forming a relative clause}

According to transformational grammar, relative clause is a surface structure representation of an embedded sentence which comes after proper or improper noun and has a coreferential NP with a head. Accordingly, sentence (5) with a deep structure converts into a surface structure sentence (6) by changing "pesar" into a pronoun in a complementizer clause:

(5) pesar-i [ke man pesar rā zadam] Farānsavi boud.

boy-RES [COMP I boy object marker beat-PAST-1sg] French be-PAST-1sg

'The boy that I beat the boy was French.'

(6) pesar-i [ke man ou rā zadam] Farānsavi boud.

boy-RES [COMP I him object marker beat-PAST-1sg] French be-PAST-1sg

'*The boy that I beat him was French.'

The pronoun used in a complementizer clause, which is related to the head (noun) of the relative clause, is called a resumptive pronoun (Trask, 1993). A resumptive pronoun can be used in the position of a subject, object or a complement of a preposition; the 
main point is that a resumptive pronoun is not obligatory and can be deleted. The other point is that Persian sentences, in which the resumptive pronouns are deleted, are considered as unmarked sentences. The following examples show the possibility of deleting resumptive pronouns, and their marked or unmarked counterparts:

(7) a. pesar-i [ke Jim rā zad.] (unmarked) boy-RES [COMP Jim object marker beat-PAST-3sg.] 'The boy that beat Jim.'

b. pesar-i [ke ou Jim rā zad.] (marked) boy-RES [COMP he Jim object marker beat-PAST-3sg.] '*The boy that he beat Jim.'

(8) a. pesar-i [ke zad-am]. (unmarked) boy-RES [COMP beat-PAST-1sg.]

'The boy that I beat.'

b. pesar-i [ke ou rā zad-am]. (marked) boy-RES [COMP him object marker beat-PAST-1sg.]

'*The boy that I beat him.'

In spite of the above fact, if the resumptive pronoun comes after a preposition, it can not be deleted:

(9) pesar-i [ke ketāb rā be ou dād-am.]

boy-RES [COMP book object marker to him give-PAST-1sg.]

'*The boy that I gave the book to him.'

(10) *pesar-i [ke ketāb rā be dād-am.] boy-RES [COMP book object marker to give-PAST-1sg.]

'The boy that I gave the book to'

The question which arises here is whether, in the case of a deleted resumptive pronoun, the movement of the constituent has taken place or not. The hypothetical answer is that if the absence of a resumptive pronoun is not the consequence of the movement of the constituent, deletion will take place in a relative clause. The question is elaborated in the following parts. 


\subsection{Resumptive pronoun in subject position}

Aresumptive pronouns can be in the subject position as in the following example:

(11) pesar-i [cpke [ıpou deraxt rā

shekaste-ast.]]

boy-RES [COMP [he tree object marker break- PRES P-3sg.]]

'*The boy that he has broken the tree.'

In Persian, the representation of a resumptive pronoun can be soundless as in the following example:
pesar-i [cp ke [ip deraxt rā
shekaste -ast.]]
boy-RES [COMP [tree
object marker break- PRES P-3sg.]]
'The boy that has broken the tree.'

The question which can be posed for Persian is whether the absence of phonetic representation of pronouns in relative clauses is the consequence of deletion or the result of the movement of a constituent to the specifier position of the complementizer phrase. This is a fundamental question and should include a reasonable syntactical evidence. If the movement of a resumptive pronoun takes place, it should meet the subjacency condition likewise other movements (Haegeman, 1992). However, presentation of evidence on the movement of a pronoun in the subject position in case of a complementizer clause in Persian is unsubstantiated for two reasons. The first issue is the property of deleting the subject in pro-drop languages such as Persian. In Persian, information of person and number has been coded in a verb, so we can delete the subject without leading to the ungrammaticality of the sentence. So, the absence of a resumptive pronoun in the subject position in Persian can be the result of the nature of being pro-drop rather than its movement. In the following example the deletion of a pronoun takes place in the surface structure, not by moving:

(13) a. Mina goft [cpke [ip ou be madrese mi-ravad.]] Mina say-PAST-3sg [COMP [she to school PRES-go-3sg.]]

'Mina said that she goes to school.'

b. Mina goft [cp ke [IP be madrese mi-ravad.]]

Mina say-PAST-3sg [COMP [to school PRES-go-3sg.]]

'*Mina said that goes to school.' 
The second issue is that presenting a strong reason for the movement or deletion of a pronoun needs to be confirmed by the subjacency condition in relative clause. The violation of the subjacency condition can be the evidence formoving the constituent. Chomsky (1981, p. 56) states that $\alpha$ movement must obey the subjacency condition. One of the condition in which we can investigate this matter is the wh-movement, which takes place in a relative clause. In this case, the movement of the resumptive pronoun accompanied by with a wh-movement leads to the violation of the subjacency condition and the creation of an ungrammatical sentence. Take the following sentence into consideration:

(14) mi-shenās-am [NPpesar-I [cpke [IP mi-dān-am [IPche kār mi-kon-ad.]]]] PRES-recognize-1sg [boy-RES [COMP [PRES- know-1sg [what do PRES-do-3sg.]]]] '*I recognize the boy that I know what does he do.'

Sentence (14) is grammatical in Persian. Because of moving both the resumptive pronoun and wh-question, the subjacency condition must be obviated and leads to ungrammatical sentence; but the matter is that Persian language has a great tendency to use wh-question in its position without moving the constituent to the first position of the sentence (Miremadi, 2008), as in the following examples:

(15) Mina dar hayāt che kār mi-konad?

Mina in yard what do PRES-do-3sg.

'What does Mina do in the yard?'

(16) Mina kojā ketaxb rā mi-barad?

Mina where book object marker PRES-take-3sg.

'Where does Mina take the book?'

(17) Mina kojā che kār mi-konad?

Mina where what do PRES-do-3sg.

'*where does Mina what do?'

In using a resumptive pronoun in the subject position in Persian, examining whether the movement of the resumptive pronoun takes place or not is problematic and there is no sufficient evidence to make conclusions. However, the object position can present some evidence for this matter. The following part deals with the study of resumptive pronouns in the object position. 


\subsection{Resumptive pronoun in object position}

Resumptive pronouns can be used in the object position as in example (18).

(18) pesar-i [cp ke [ıp Mina ou rā davat-xāhad kard.]] boy-RES [COMP [Mina him object marker invite-FUTURE-3sg.]]

'*The boy that Mina will invite him.'

The resumptive pronoun in the object position can be deleted, as the following example shows:

(19) pesar-i [CP ke [IP Mina davat-xāhad kard.]] boy-RES [COMP [Mina invite-FUTURE-3sg.]]

'The boy that Mina will invite.'

In the following sentence (20), we use " $\mathrm{t}$ " in the position of the resumptive pronoun; that means we hypothesize that the movement has taken place.

(20) mi-shenās-am [Np pesar-i [cpke [IP Mina goft [IP Jim t fardā PRES-know-1sg [boy-RES [COMP [Mina say-PAST-3sg [Jim tomorrow davat -xāhad kard.]]]] invite-FUTURE-3sg.]]]]

'*I know the boy that Mina said Jim will invite tomorrow.'

In the above sentence, [CP ke [IP Mina goft]] is considered as a barrier and the trace can not be coreferential with the head "pesar". It means that the reference of the trace is in the domain of second IP. Therefore, it is expected that the second constituent would not move because this would lead to the obviation of subjacency condition and further the ungrammaticality of the sentence. This can be shown empirically by writing a whquestion instead of "fardā" (tomorrow):

(21) mi-shenās-am [NP pesar-i [cP ke [IP Mina goft [IP Jim t che moqe PRES-know-1sg [boy-RES [COMP [Mina say-PAST-3sg [Jim when davat -xāhad kard.]]]] invite-FUTURE-3sg.]]]]

'*I know the boy that Mina said when will Jim invite.' 
In example (20) "fardā: tomorrow" is in the unmarked position, which is the meaning in its deep structure position. In case "che moqe: when" is moved from its position to before "Jim", we encounter with two cases. If we have another movement before the movement of "che moqe", the movement of the second constituent leads to the obviation of the subjacency condition and hence to the ungrammaticality of the sentence. On the other hand, if the movement takes place before the movement of "che moqe", the sentence is grammatical. The ungrammaticality of the following sentence leads us to conclude that before the movement of "che moqe" we had had another movement, unless the ungrammaticality of the following sentence is not justifiable.

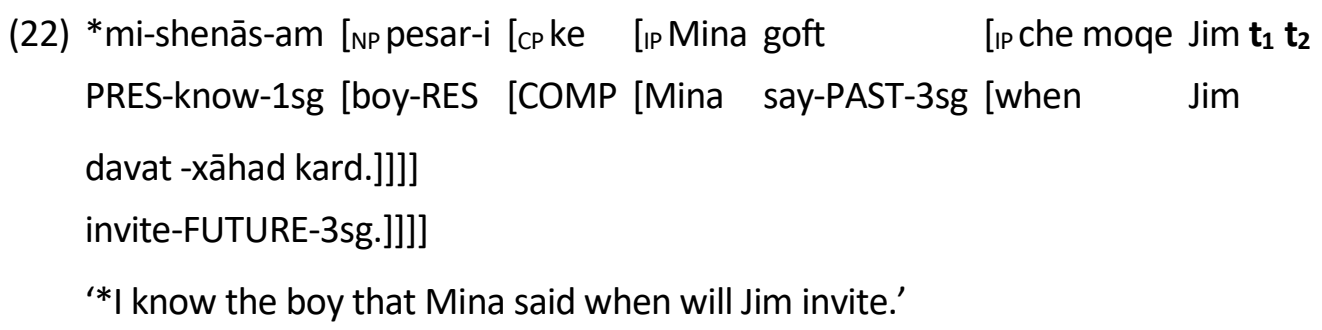

We may therefore conclude that the ungrammaticality of the above sentence is justifiable when we believe in a presence of some other movement before the movement of "che moqe". In the above clause, the movement of the resumptive pronoun had taken place and because of the movement of the second constituent, the subjacency condition is obviated; therefore, we expect that in the case of inserting the resumptive pronoun, the above sentence becomes grammatical. This is demonstrated by the following example.

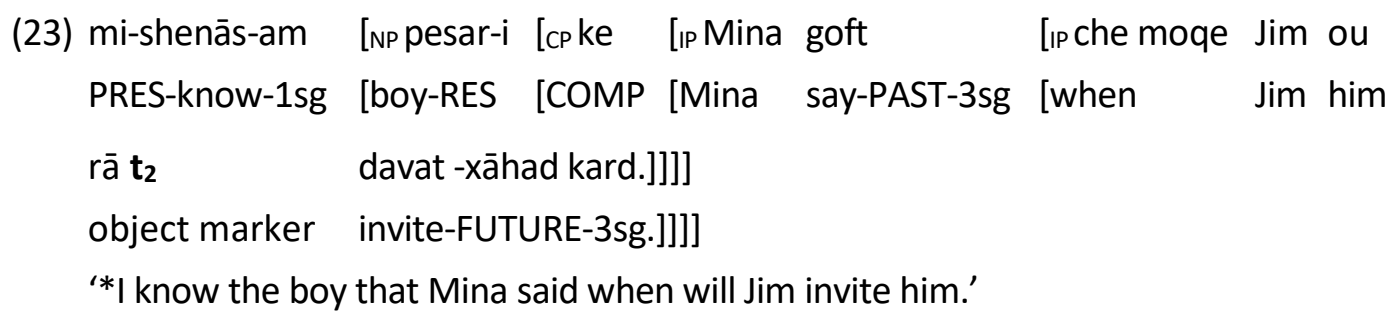

At this point we can conclude that if we have a movement in the complementizer clause in which the resumptive pronoun in the object position does not have a phonetic representation in s-structure, it is reasonable that we have a movement in the subject position. Consequently, relative clauses may also represent the cause of the movement. Another question which arises here is whether there is other evidence to support this claim. Theta theory presents other evidence for approving the movement and the existence of an empty category in Persian relative clauses. 


\subsection{Theta theory and the movement in relative clauses}

Theta theory in government and binding theory deals with the valency of the verbs (Trask, 1993). Determining the necessary constituents of a sentence through predicate logic is a part of theta theory (Haegeman, 1992) and this is the lexical information which determines the number of arguments of a verb (Cowper, 1996). Verbs which take an object are two place predicates (Hurford \& Heasly, 1996). The verb "davat kardan: to invite" is a two place predicate, which gives the theta role "patient" to the object position as in the following example:

(24) Mina ou

rā

davat-xāhad kard.

Mina him/her object marker invite-FUTURE-3sg.

'Mina will invite him/her.'

Deletion of one of the arguments leads to the ungrammaticality of the sentence:

(25) *Mina davat-xāhad kard.

Mina invite-FUTURE-3sg.

'*Mina will invite.'

Let us consider the case (26), in which the resumptive pronoun does not have a phonetic representation in the object position; if we believe in deletion, we will encounter a problem.

(26) mi-shenas-am pesar-i [cPke [IP Mina davat-xāhad kard.]]

PRES-know-1sg boy-RES [COMP [Mina invite-FUTURE-3sg.]]

'I know the boy that Mina will invite.'

The object position of the verb "davat kardan: to invite" is governed and receives a case. The position which receives a case must have a phonetic representation (Cowper, 1996). In case of believing in deletion, the grammar wrongly predicts that the above sentence must be ungrammatical, and so its grammaticality is unjustifiable. But if we believe in the movement and the substitution of the constituent, the absence of a phonetic representation is not problematic because the moved constituent settles in the position with no case. Deletion of an object leads to the change of meaning, which in other words means that the transformation changes the meaning. This goes against the Katz-Postal (1964) hypothesis, which says that transformations preserve the original meanings. At this point it is therefore necessary to believe in the movement of a constituent in relative clauses where pronouns in the object position are soundless. 
In the object position, we can intervene between the head and the complementizer clause by inserting other clauses without making a sentence ungrammatical, such as in the following example.

(27) mi-shenas-am pesar-i [cP ke [IPfekr mi-konad [IP Mina xāb-dide-ast PRES-know-1sg boy-RES [COMP [think-PRES-3sg [Mina dream-PAST-3sg [IPhame t doust-dārand [ıpou rā bebinand.]]]] [all like-PRES-3pl [her object marker see-PRES-3pl.]]]]] '*I know the boy that he thinks Mina had dream all like to see her.'

Example (27) shows that we can not consider the meaning of the resumptive pronoun (in doust dāshtan clause) in relation to "pesar-i" (head). Instead, the complementizer clause acts independently from the head both from the point of meaning and the point of syntax. The object of the verb "doust dāshtan", which is the soundless resumptive pronoun, must thus exist to project but the grammar nevertheless wrongly predicts the above sentence as ungrammatical. According to the above claims, we may conclude that rather than deletion it is the movement that takes place in relative clauses. If a relative clause without a resumptive pronoun is the cause of the movement, the moved constituent must leave behind a trace. The following part discusses the nature of this trace.

\subsection{The nature of the trace of the resumptive pronoun movement}

The authors have tried to prove the existence of an empty category in Persian relative clauses so far, and used the predicate logic, theta theory, subjacency condition, and Katz-Postal hypothesis to prove that the movement of a resumptive pronoun takes place in relative clauses. Since the movement of the constituents leaves behind a trace, it is necessary to study the nature of such a trace.

The trace of a resumptive pronoun in Persian clauses is considered as one of the empty categories. The idea of the existance of empty categories is one of the characteristics of the government and binding theory, and it refers to the position that is active syntactically but it does not have any phonetic representations (Cowper, 1996). Four types of empty categories are differentiated in this theory: NP- trace, Wh-trace, pro and PRO. These empty categories have different distributions in sentences according to different principles of universal grammar (Horrocks, 1987) and they always occupy the position of a noun phrase in a sentence. Several parts of the government and binding theory such as the control theory, government theory, and binding theory are related to empty categories (Trask, 1993). Consider the following sentence with a relative clause: 
(28) mi-shenās-am [Np pesar-i [cP ke [IP Mina e davat-xāhad kard.]]] PRES-know-1sg [boy-RES [COMP [Mina invite-FUTURE-3sg.]]]

'I know the boy that Mina will invite.'

The empty category " $\mathrm{e}$ " is in the position where it is governed and receives a case. Consequently, it is not possible for " $e$ " to be PRO because PRO can not be governed (Lasnik, 1988). The empty category " $\mathrm{e}$ " can not be the trace of NP, because the trace of NP does not receive case (Lasnik, 1988). As for other empty categories, pro and whtrace are left to be evaluated. The category of pro receives case and is governed (Carnie, 2002) and just the principle $B$ from the government and binding theory is applicable to it (Chomsky, 1982, p. 78). The "e" category is in the position which is governed and receives case, so it is expected to be pro. However, if " $\mathrm{e}$ " is perceived as pro, it is not limited by subjacency condition because pro is not the result of a movement. If " $\mathrm{e}$ " is the same as pro, the ungrammaticality of the following sentence will be unjustifiable:

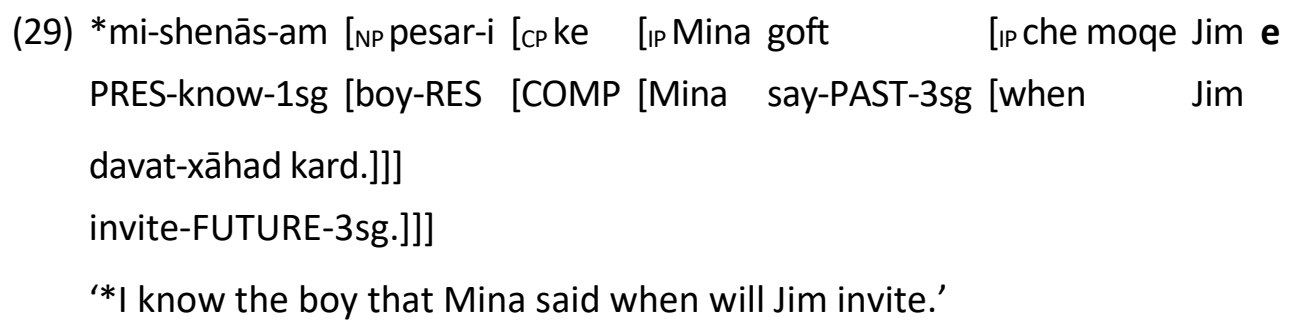

The above sentence is ungrammatical when a movement had taken place before whmovement in a relative clause. Pro is not the result of a movement and the ungrammaticality of the above sentence is the witness against the matter that " $\mathrm{e}$ " can not be pro.

The only option remaining is the wh-trace, the position from which the whquestion moves and receives case. When a wh-question moves, it must obey the subjacency condition. Ungrammaticality that rises from such a situation is demonstrated by the following sentence:

(30) *mi-shenās-am [np pesar-i [cpke [Ip Mina goft [Ip che moqe Jim e t PRES-know-1sg [boy-RES [COMP [Mina say-PAST-3sg [when Jim davat xāhad kard.]]] invite-FUTURE-3sg.]]]

'*I know the boy that Mina said when will Jim invite.' 
The ungrammaticality of the above sentence is justifiable when we believe that another wh-movement had taken place before the movement of "che moqe", leaving behind a trace. In other words, the position in which "che moqe" wants to settle had been occupied before. If this claim is true, inserting a resumptive pronoun leads to grammaticality of the sentence as the following sentence shows:

(31) mi-shenās-am [NP pesar-i [cP ke [IP Mina goft [IP che moqe Jim ou PRES-know-1sg [boy-RES [COMP [Mina say-PAST-3sg [when Jim him

rā $\mathbf{t}$ davat -xāhad kard.]]]

object marker invite-FUTURE-3sg.]]]

'*I know the boy that Mina said when will Jim invite him.'

So, there must be a soundless reference to " $\mathrm{e}$ " in Persian relative clauses without a resumptive pronoun. This element, which is shown by " 0 " in texts, has been produced in a D-structure as the complement of the verb "davat kardan", and has moved to [spec, CP] and left behind a trace which is shown by " $\mathrm{e}$ ". Thus, " $\mathrm{e}$ " is the trace of a whquestion. The D-structure and S-structure of the complementizer clause are presented respectively in the following:

(32) [NP pesar-i [cp ke [IP Mina goft [IP Jim o davat-xāhad kard]]] [boy-RES [COMP [Mina say-PAST-3sg [Jim invite-FUTURE-3sg]]] rā mi-shenās-am.

object marker PRES-know-1sg.

'*I know the boy that Mina said Jim will invite.'

(33) [NP pesar-i [CP o ke [IP Mina goft [IP Jim e davat- xāhad kard]]] [boy-RES [COMP [Mina say-PAST-3sg [Jim invite-FUTURE-3sg]]] rā mi-shenās-am.

object marker PRES-know-1sg.

'*I know the boy that Mina said Jim will invite.'

"o" is one of the empty categories (Haegeman, 1992) that has not been analyzed so far in Persian. This element is called an empty operator. The question which arises here is that what kind of empty category "o" is. " 0 " is not a trace, because it exists in a Dstructure. The nature of this category is not so specified, but Jaeggli (1981) considers "o" as being the same as PRO. PRO settles in the position without government (Chomsky, 1981, p. 74), "o" is in the position which governs. The condition of not having 
government for PRO is not one of the principles of the theory but the consequence of the PRO characteristic ([+ pronoun, +anaphor]). Therefore, in a D-structure PRO can settle in a position that governs, and since the government and binding theory show its function in S-structure, its occurrence in the position where government is donated is not problematic (Chomsky, 1981, p. 74). In a S-structure PRO moves to the position without government, it means to the specifier position of the complementizer clause.

\subsection{Movement and the principle of the empty category}

Above we have shown that there is a soundless category "o" in Persian relative clauses. "o" is one of the arguments of a verb in a D-structure which is transferred to [spec, CP] in a S-structure. Jaeggli (1981) considers "o" as a PRO, which necessarily makes it move to the position without government in a S-structure. We can thus conclude that CP is a barrier for government, as in the following sentence.

(34) [NP pesar-i [CP O ke [IPJim e davat-xāhad kard]]] rā mi-shenās-am. [boy-RES [COMP [Jim invite-FUTURE-3sg]]] object marker PRES-know-1sg.

'I know the boy that Jim will invite.'

"o" can not govern its trace. The existence of a complementizer "ke" and its characteristic of being a barrier prevents "o" to govern its trace. According to the empty category principle, traces must be governed (Culicover, 1997; Lasnik, 1988), and following it would make the above sentence ungrammatical. To observe the empty category principle and hence the grammaticality of the above sentence, Pesetsky (1982, p. 306) presents a rule for this structure that converts the empty category "o" and the complementizer to a constituent which has all of the characteristics of the empty category. In this case, the trace is properly governed. This shows that the complementizer of a relative clause is not a usual complementizer, but it acts as a resumptive pronoun. It is the first time that the issue, which offers a justification for some of the linguistic realities in Persian, has gained attention. Again, the fact is that a complementizer can not be deleted in a relative clause, and its deletion leads the sentence to be ungrammatical:

(35) [cp pesar-i ke Jim davat-xāhad kard] doust-e-man ast.

[boy-RES COMP Jim invite-FUTURE-3sg] friend-of-mine be-PRES-3sg.

'The boy that Jim will invite is my friend.' 
(36) *[cp pesar-i Jim davat-xāhad kard] doust-e man ast.

[boy-RES Jim invite-FUTURE-3sg] friend-of-mine be-PRES-3sg.

'The boy Jim will invite is my friend.'

The above issue is against the nature of a complementizer in the following sentences where a complementizer clause is used in a position of one of the arguments of a verb. In this case the complementizer "ke" is optional and can be deleted without leading to the ungrammaticality of the sentence as the following examples show:

(37) shenide-am [cpke Jim pesar-i rā davat-xāhad kard.]

hear-PAST-1sg [COMP Jim boy-IND object marker invite-FUTURE-3sg.]

'I heard that Jim will invite a boy.'

(38) shenide-am [cp Jim pesar-i rā davat xāhad kard.]

hear-PAST-1sg [Jim boy-IND object marker invite-FUTURE-3sg.]

'I heard Jim will invite a boy.'

\subsection{Complementizer in relative clause}

The above sections have shown that wh-movement also takes place in Persian relative clauses without pronoun, and that the soundless category " 0 " in a D-structure exists in the governor position. Forming a relative clause does not necessarily need a movement in Persian, which is demonstrated by the following example.

(39) mi-shenās-am [NP pesar-i [cP ke [IP ou rā

davat -karde-i.]]]

PRES-know-1sg [boy-RES [COMP [him object marker invite-PRESENT P-2sg.]]]

'*I know the boy that you have invited him.'

In the above sentence, the resumptive pronoun exists in its first position in a Dstructure. The result is that the movement has not taken place in this structure, and therefore the complementizer "ke" is expected to have the possibility of being deleted. However, despite our expectation the deletion of the complementizer leads to the ungrammaticality of the sentence:

(40) *mi-shenās-am [NP pesar-i [CP [ıP ou rā davat-karde-i.]]]

PRES-know-1sg [boy-RES [ [him object marker invite-PRESENT P-2sg.]]]

'*I know the boy you have invited him.' 
A justification for this behavior can be found in diachronic changes. Several studies have tried to find the origin of a relative clause and its positions in the Indio-European mother language (Harris \& Campbel, 1995). Kent (1953) believed that relative clauses in Old Persian were of different types, but most of them had the role of a limiter. In Old Persian, relative, question, complement and conjunction had different forms. According to Abolqasemi (1996, p. 358) complementizers "hya" and "yox" were placed after a noun and could have agreement with a noun in number, case and gender.

\section{(41) Old Persian:}

Baga vazrka Ahuramazdā hya imaxm buxmixm adax

God Big Ahuramazda who this universe create-PAST-3sg

'Ahuramazda is the big God who created this universe.'

In the above example "hya" has agreement with the noun "Ahuramazda" in agentive case.

\section{(42) Old Persian:}

axat hex mraom ažm yox ahurox mazdax.

Then him tell-PAST-1sg I that Ahuramazda.

'Then, I told him that I am Ahuramazda.'

The complementizer "yox" has agreement with the pronoun "az̄m" in agentive case, gender (male) and number (singular).

In Old Persian, the complementizer had different types of cases such as agentive, accusative and genitive. It also conjugated for singular, dual, plural, masculine and feminine (Abolqasemi, 2016, p. 19). This issue means that the complementizer in a relative clause is not only a complementizer in Persian. Even though surface representations in the Persian language system are missing, the roles have been kept. Thus having case for a complementizer in Persian offers a justification for its impossibility to be deleted. Still, this matter needs a deeper investigation.

In Middle Persian the relative and question forms were combined to "ix", but the complement and conjunction still had different forms (Abolqasemi, 2016, p. 19); In Modern Persian "ke: that" is replaced for all the above forms (Estaji, 2000) and in Modern Persian we consider "ke" a complemenizer of a relative clause. 


\section{Conclusion}

Regarding relative clauses, the article mentioned three approaches. The first approach considers "ke" as a wh-word which moves from its original position to the specifier position of the complementizer phrase. The second approach considers the movement of an empty operator to [spec, CP]. The third approach provides a view in the framework of the Minimalist program. This study followed empty operator approach in the framework of GB. The Persian relative clauses can be produced either with or without a resumptive pronoun. In the usage of the relative clause in which the resumptive pronoun is deleted, the soundless empty category is syntactically active and moves to [spec, CP]. Nevertheless, we do not have a complete justification for the soundless empty category " $\mathrm{o}$ " in Persian. This may due to the Persian language and its system, which can not present enough evidence for proving the existence of the soundless empty category and the movement.

This article showed the existence of an empty category in Persian relative clauses. It further presented a justification for "ke" being obligatory in Persian relative clauses, and case in Old Persian was presented. We used the predicate logic, subjacency condition and diachronical view to prove this category.

\section{References}

Abolqasemi, M. (2016). A Historical Grammar of Persian Language. Tehran: Samt.

Abolqasemi, M. (1996). The History of Persian Language. Tehran: Samt.

Ahangar, A. A. (2000). The Subordinate Clause Construction in Persian based on Government and Binding Theory. Ph.D. Dessertation. Tehran University.

Carnie, A. (2002). Syntax: a generative introduction. Chichester, West Sussex, UK: WileyBlackwell.

Chomsky, N. (1982). Some concepts and consequences of the theory of government and binding. Cambridge, Mass: MIT Press.

Chomsky, N. (1981). Lectures on government and binding. Studies in generative grammar. Dordrecht: Foris.

Chomsky, N. (1995). The minimalist program. Cambridge, Mass: MIT Press.

Comrie, B. (1989). Language universals and linguistics typology. Oxford: Basil Blackwell.

Cowper, E. (1992). A concies introduction to syntactic theory. Chicago, London: Chicago University Press.

Culicover, P. W. (1997). Principles and parameters: an introduction to syntactic theory. Oxford: Oxford University Press.

Estaji, A. (2000). Historical study of "ke" multifunctions in Modern Persian. Journal of Linguistics and Khorasan Dialects.

Haegeman., L. (1992). Introduction to government and binding theory. Oxford: Blackwell. 
Harris, A. C., \& Campbel, L. (1995). Historical Syntax in Cross-Linguistic Perspective. Cambridge: Cambridge University Press.

Hornstein, H., Nunes, J., \& Grohmann, K. (2006). Understanding minimalist. Cambridge: Cambridge University Press.

Horrocks, G. (1987). Generative grammar. London: Longman.

Hurford, J., \& Heasly, B. (1996). Semantics: a course book. Cambridge: Cambridge University Press.

Jaeggli, O. (1981). Topics in Romance syntax. Dordrecht: Foris.

Katz, J. J., \& Postal, P. M. (1964). An integrated theory of linguistic description. Cambridge,. Mass: MIT Press.

Kayne, R. (1984). Connectedness and binary branching. Dordrecht: Foris.

Kent, R. G. (1953). Old Persian. New Haven: American oriental society.

Khayampour, A. (1973). Persian Grammar. Tabriz: Tehran Bookshop.

Lasnik, H. (1988). A course in GB syntax: lectures on binding and empty categories. Cambridge, Mass.: MIT Press.

Lazard, G. (1957). Grammaire du persan contemporain. Paris: Klincksieck.

Miremadi, S. A. (2008). Persian Syntax, A G. B-Based Analysis. Tehran: Samt.

Pesetsky, D. (1982). Paths and Categories. Doctoral Dissertation. MIT Press.

Radford, A. (2006). Minimalist syntax: exploring the structure of English. Cambridge: Cambridge University Press.

Riemsdijk, H., \& Tushyeh, H. (1998). A contrastive analysis of English and Arabic in relativization. Papers and studies in contrastive linguistics, 34, 141-152.

Riemsdijk, H., \& Edwin, W. (1986). Introduction to the theory of grammar. Cambridge, MA: MIT Press.

Safavi, K., (1994). Some Properties of Persian Relative Clause. Proceedings of the $2^{\text {nd }}$ Conference of Persian Linguistics. Allameh Tabatabaie University, Tehran.

Taghvaipour, M. A. (2005). Persian Relative Clause in Head-driven Phrase Structure Grammar. Ph.D. Desertation. University of Essex.

Trask, R. L. (1993). A dictionary of grammatical terms in linguistics. London and New York: Routledge.

Windfuhr, G. L. (1978). Persian Grammar: History and State of its Study. The Hague: Mouton Publishers.

Youhanaee, M. (1997). The Acquisition of the English Complementizer Phrase by Adult Persian Speakers. Ph.D. Dissertation. University of Essex. 